\title{
IFAS Community Development: In Search of a Common Understanding of Community 1
}

\author{
Mark A. Brennan ${ }^{2}$ \\ This paper is the first in a series of discussions \\ on community development. This series will include \\ specialized papers on civic engagement, community \\ action, and other topics important to the development \\ of community.
}

\section{Introduction}

Rarely a day goes by that we don't hear about efforts to build community, expand community capacities, foster community development, or encourage community engagement. The attention given to community is important, and provides insight into what we inherently believe to be important in our lives. Images of community depict fond notions of togetherness, social connections, and support from other residents. While international events and the pace of modern life impact us, it is the local day-to-day interactions with people that shape our lives. Such routine interaction and the social ties it fosters is the single most important factor in our efforts to develop community.
In spite of the importance we place on community, attention to the critical component of social interaction has at times been divided. In the last decade, there have been great calls for restoring our sense of community, social capital, and the stock of social connections that may have once existed (Putnam 1997). In contrast, there are those that believe that community no longer exists and is irrelevant in our modern, globally connected world. Both views have been shaped by real and perceived changes in society and social structures over the past century. For example, gated communities, the continuing growth of the suburbs, increased commuting times to work, and smaller families are seen as eliminating, or at least severely limiting, connections to our neighbors. In our global and increasingly interconnected world, local life and the connections among local people are often seen as secondary to national social and economic development. All of these conditions shape our perceptions of what community is. They also shape what we perceive as the options for its development.

1. This document is FCS 9205, one of a series of the Department of Family, Youth and Community Sciences, Cooperative Extension Service, Institute of Food and Agricultural Sciences, University of Florida. Publication date: July 2004. Reviewed by Mickie Swisher, PhD, Department of Family, Youth and Community Sciences, Cooperative Extension Service, Institute of Food and Agricultural Sciences, University of Florida and A.E. Luloff, PhD, Department of Rural Sociology, University of Florida, Gainesville, FL, 32611. Please visit the EDIS website at http://edis.ifas.ufl.edu

2. Mark A. Brennan, PhD, Assistant Professor of Community Development, Department of Family, Youth and Community Sciences, Cooperative Extension Service, Institute of Food and Agricultural Sciences, University of Florida, Gainesville, FL, 32611.

The Institute of Food and Agricultural Sciences (IFAS) is an Equal Employment Opportunity - Affirmative Action Employer authorized to provide research, educational information and other services only to individuals and institutions that function without regard to race, creed, color, religion, age, disability, sex, sexual orientation, marital status, national origin, political opinions or affiliations. For information on obtaining other extension publications, contact your county Cooperative Extension Service office. Florida Cooperative Extension Service//nstitute of Food and Agricultural Sciences / University of Florida / Larry R. Arrington, Interim Dean 
The confusion over community, and often the failure of efforts to develop it, stem from a casual and inconsistent use of the term. When asked, most people we talk to have a definition of community. It is also the case that these definitions will be markedly different depending upon whom we ask. This is in part due to the lack of a consistent definition as to what constitutes community, development, and civic engagement. This lack of clarity has led to policies and programs that only impact select geographic areas or select groups of people, and generally do not benefit the needs and wants of the entire local area. These same policies routinely ignore the unique social and cultural components of the community that are vital to effective programs and policies.

To impact our programs and best serve our populations, a need exists for local government, citizens groups, extension agents, and other policy-makers to have a consistent definition of what constitutes community. We need to have the same (or at least similar) images of community in mind when we discuss, plan, implement, and evaluate programs designed to enhance local well-being.

\section{Community: A Process of Interaction}

Overall, most definitions of community have one or more of the following components:

1. A geographic or territorial dimension, most often referring to a place or locality. This is simply seen as a place where people live;

2. A human life dimension containing a local society highlighted by social organization in which members satisfy their basic needs.

People residing in such locations have their needs met through organizations and institutions which provide services, government, and social order;

3. A process of locality-oriented social actions in which residents of a community express their common interests and needs. (Wilkinson 1991; Luloff and Swanson 1995; Bridger and Luloff 2003)
Yet the presence of these elements does not necessarily mean that community might exist. It is true that place and locality is an important component to community. However, community is much more than a geographic location. It is a social and psychological entity that represents a place, its people, and the relationships that exist there (Wilkinson 1991). Interaction among local people serves to provide a basis for conscious community wide efforts aimed at improving social well-being (Wilkinson 1991; Luloff and Swanson 1995). In this setting, civic engagement, community action, and social participation are seen as being central to the emergence of community and its development.

A more accurate definition of community views locality as a place where people live and meet their common daily needs together. Rather than a geographic boundary, such places can be seen as a comprehensive network of individual relationships that meet routine needs and express common interests. However, it is necessary to recognize that not all relationships serve to create the sense of connection that characterizes community. It is only through a process of deliberate, focused, and interrelated actions that diverse segments of local society express their common interests and needs. This process of interaction culminates in the emergence of community. In sum, community is an always changing variable shaped by social interaction.

While often overlooked, these ideas are nothing new. Community theorist Ferdinand Toennies stressed that community existed when institutions and individuals were drawn together not as a result of support needs, but because social togetherness is a positive condition that helps form a unified whole (Toennies 1957). Sociologist Ken Wilkinson saw community from an interactional perspective, where the emergence of community was a dynamic process of bringing people together (Wilkinson 1991). Through interaction, an entity can emerge that is far greater than the sum of its parts. This focus does not imply that social structures or systems are unimportant. The local economy, sociodemographic characteristics of the population, local organizations, natural resources, and institutions are vital to the make up of the community and its residents (Luloff 
and Bridger 2002). However, these factors serve as the backdrop for local life and the relationships among residents.

Interaction is a pervasive and constant feature of local life that provides substance to its ecological, cultural, organizational, and social psychological aspects (Wilkinson 1991). Without such interaction, community could not exist. Interacting with others gives direction to processes of collective action and social participation, and is a source of common identity (Wilkinson 1991).

Community is the local setting for contact between the individual and the wider society. In this setting most people meet their daily needs. As they share a common territory they interact with one another on a routine and substantive basis. These interactions increase awareness of local issues and problems and can lead to the development of purposive and focused actions aimed at enhancing local well-being. This process occurs only as diverse segments of a locality recognize their common needs, establish channels of communication, and work cooperatively to meet their needs.

\section{Conclusion}

As a result of changes that have taken place in the social, cultural, and political landscape over the past century, local societies have become increasingly prevalent, but community has become something much rarer. Under such modern conditions, the actions of local residents in support of their community are vital to the community's social and economic viability. However, the purposive actions of local residents emerge only when the proper environment is present. Consequently, community can exist only as long as the people in the area care about each other and the place in which they live. This care is expressed in the coordinated actions they take part in to enhance local well-being.

While many theories and definitions of community exist, most focus only on the place or the structures that are present. It is interaction in various settings that links people together and facilitates the communication of local needs to the broader society. Such interaction serves to empower community residents and provide a mechanism for maintaining social networks and channels of communication that cut across social and cultural divides. By increasing venues for interaction, partnering with diverse community groups, and bringing together a wide spectrum of local residents, we can lay the basis for community action and development.

The definition of community presented here is not meant to present a romantic or idealized notion of local harmony and solidarity. Our localities are often dominated by self-interest, outside development, distrust, conflict, and other negative conditions. This, however, does not mean that community cannot exist. Community emerges out of interaction between diverse social groups, often with clashing or at least distinctly different points of view. This interaction facilitates the coming together of such groups to assess their common needs and increase awareness of issues facing all residents. From this process, residents form plans of action that benefit all involved and the community in general. This willingness to act is not based on altruistic feelings or beliefs that their efforts will be rewarded.

Development of community is based on the collective needs of many groups who have realized common ground. Meeting these needs contributes to the greater well being of the locality.

In closing, it is important to be reminded that community is attainable. While it is true that our society has changed greatly over the last century, community has not become irrelevant. In our modern world, people are often hesitant to commit themselves, their time, and their resources to the resolution of various social issues and problems. Nonetheless, many people routinely do. This is a result of the sense of community that is fostered through interaction, communication, and understanding of common needs.

When working with and planning for our communities, we need to look beyond government and other structures that are in place. While these are of course important, we need to focus first on the local people. We need to focus on how they interact and feel about each other, how attached they are to the locality, and how they can contribute to local well-being. We need to look at the process of how and why they participate in their communities. 
Assessing such characteristics provides a clear target and focus for our efforts. It allows us to directly measure who is active in the communities and who is not. Steps can then be taken to encourage inclusive community wide participation. Such assessments also allow us to focus on the uniqueness and diversity that exist in each of our communities. By focusing on these characteristics we can create programs specifically designed to meet the particular social and economic needs of the locality.

This paper has provided a definition and discussion of what community is. Future IFAS Community Development papers in this forum will build on this definition, and explore ways in which we can bring broad segments of the community together. Community development, local level action, and civic engagement all contribute to this process. Future publications will discuss these in more detail and provide applied steps that can be taken to contribute to the emergence of community.

\section{References}

Luloff, A.E., and J. Bridger. 2003. "Community Agency and Local Development." Pp. 203-213 in Challenges for Rural America in the Twenty-First Century, edited by Brown and Swanson. University Park, PA: Pennsylvania State University Press.

Luloff, A. E. and L. Swanson. 1995. "Community Agency and Disaffection: Enhancing Collective Resources." Pp. 351-372 in Investing in People: The Human Capital Needs of Rural America, edited by Beaulieu and Mulkey. Boulder, CO: Westview Press.

Putnam, R. 1997. Bowling Alone: The Collapse and Revival of American Community. New York, NY: Touchstone Books.

Toennies, F. 1957. Community and Society. East Lansing, MI: Michigan State University Press.

Wilkinson, K. 1991. The Community in Rural America. New York, NY: Greenwood Press.

\section{Suggested Reading}

Bender, T. 1978. Community and Social Change in America. New Brunswick, NJ: Rutgers University Press.

Christenson, J. A. and J. W. Robinson. 1989. Community Development in Perspective. Ames, IA: Iowa State University Press.

Northeast Regional Center for Rural Development. Community: A Biography in Honor of Ken Wilkinson.

http://www.cas.nercrd.psu.edu/Community/ community.html

Community Development Institute East. http://www.ext.wvu.edu/cdi-east/

Flora, C. B., J. Flora, et al. 1992. Rural Communities: Legacy and Change. Boulder, CO: Westview Press.

Granovetter, M. 1973. "The Strength of Weak Ties." American Journal of Sociology 78(6): 1360-1380.

Lyon, L. 1999. The Community in Urban Society. Long Grove, IL: Waveland Press.

Southern Rural Development Center. http://srdc.msstate.edu

Wilkinson, K. 1986. "In Search of the Community in the Changing Countryside." Rural Sociology 51(1): 1-17. 